\title{
The Changing Nature of Death Penalty in Vietnam: A Historical and Legal Inquiry
}

\author{
Kien Tran ${ }^{1,2, *(1)}$ and Cong Giao $\mathrm{Vu}^{1}$ \\ 1 School of Law, Vietnam National University, Hanoi, E1, 144 Xuan Thuy, Hanoi 10000, Vietnam \\ 2 Institute for Social Development Studies, Hanoi, Suite 1804, Penthouse, The Garden, Me Tri Road, \\ Nam Tu Liem District, Hanoi 10000, Vietnam \\ * Correspondence: trankien@vnu.edu.vn
}

Received: 9 April 2019; Accepted: 7 August 2019; Published: 12 August 2019

\begin{abstract}
This research centers on the change in the nature of the death penalty as expressed in law and practice throughout Vietnam's history with a focus on modern time. Using a set of typical legal research methods, in particular, legal history, doctrinal research, philosophy of law and, sociology of law, the article analyzes the change and reform of capital offences in Vietnamese laws. It is revealed through our research that the nature of the death penalty has been fundamentally changed from an instrument of power and coercion during much of the history of the country to a manifestation of justice based on the ideas of rule of law and human rights that started to emerge in the early twentieth century, especially from 1986 onwards. As a result, the number of capital offences has been gradually reduced in three modern Criminal Codes. However, it is also noted that the number of capital sentences and executions appears to remain unchanged, even slightly increased. This creates a paradox that opens and invites a future, interdisciplinary research to thoroughly investigate the problem in the country. The article also argues that as the death penalty finds its moral and legal justifications along with the rise of the number of death sentences given to many serious criminal cases, the death penalty appears to find support among the public. In addition, the political sensitivity of the issue, as expressed through the prohibition on the disclosure of the death penalty data, will inhibit discourse on the problem. Together, they will maintain the existence and application of the death penalty in Vietnam in the time to come.
\end{abstract}

Keywords: Vietnam; death penalty; criminal law; justice; human rights; legal reform

\section{Introduction}

Capital punishment, or sentence, is a sentence that imposes the death penalty, the execution of an offender sentenced to death after conviction by a court of law of a criminal offence ("capital punishment", [1]). This definition of capital punishment indicates a number of qualities that capital punishment sustains in the contemporary world. In principle, it is a criminal penalty and the most severe form of punishment. Provided for in a legal instrument, often a Statute or an Act, imposed by a court of law through a legal process on an offender for their committing a prohibited criminal act prescribed in a code of law. However, it has not always been the case in the past. The historical evolution of capital punishment from an extra-judicial or personal revenge, determined by a wide range of factors (culture, politics, ideology, religion) to a prescribed legal punishment administered by a state authority, to contemporary objection reflects the triumph of the notion of human rights and rule of law in an increasingly globalized world [2]. In the case of Vietnam, as later discussed, the death penalty includes both full and summary executions allowed by a court of law [3].

To start with, there seems to be nothing more contentious than the issue of the death penalty, especially since the right to life started to emerge as one of the most fundamental human rights with 
its idea and advocacy dated as far back as the enactment of Magna Carta and later the Declaration of the Rights of Man and of the Citizen. As of 2018, Amnesty International reports that 106 countries have abolished the death penalty in law for all offences and 142 countries have abolished the death penalty in practice [4]. While the number of countries executing death sentences has reduced from 40 countries in 1997 to 23 in 2017, the recorded number of executions was at least 993 [4,5]. Moreover, 21,919 are on death row as of the end of 2017 [4]. Vietnam remains a retentionist according to Amnesty International $[6,7]$.

The tension occurs mainly between two main schools of thought. On the one hand, there is a growing consensus among the international community about the need to abolish the death penalty with many arguments pertaining to the nature, role, and ineffectiveness of the death penalty in combating crimes, a better adherence of sovereign states to universal human rights standards to which the right to life is the most fundamental, and more interestingly, the emergence and reception of modern Western criminal justice jurisprudence into many developing retentionist countries [8].

On the other hand, of the 56 retentionist countries, most of them are now located in the regions of Asia, the Middle-East, North Africa, and the Caribbean [9]. They rely on a wide range of justifications for maintaining the most brutal punishments ranging from culture, politics, ideology, religion, law, history, and even economics [10]. However, there are signs suggesting that they are moving away from the death penalty with slow progress [11].

Central to this debate is the idea of justice and retributive justice as a legitimate justification for the existence and use of the death penalty. As a form of justice, retributive justice contemplates that those who commit a crime, especially a serious one, morally deserve to receive a proportionate punishment, including death $[12,13]$.

In this context of change, Vietnam represents a prime, unique case to understand the nature, role, and issues in relation to the death penalty and justice. For the last two hundred years, Vietnam has undergone a number of changes in its ideological, political, economic, legal, and even cultural foundations. Vietnam has transitioned from a monarchical regime to a colonial society to socialism, before democracy and a market-based economy found its way to Vietnam in the late twentieth century while retaining a socialist ideology [14-16]. However, regardless of the type of societal structure in Vietnam, the death penalty remains an inevitable phenomenon, playing a significant role and being employed enthusiastically by ruling governments. What is of vital difference is that in a typical Vietnam, the death penalty demonstrates a difference in nature, role, and function.

Much has been written about the death penalty in Vietnam in both Vietnamese and English. This has supported the creation of a body of meaningful discussions and literature on the problem of capital punishment in the country, even to the point of facilitating a number of key legal reforms on the subject recently. However, these bodies of literature do not escape several understandable shortcomings. The Vietnamese literature on the death penalty often depicts the problem from a purely descriptive and doctrinal perspective. Current literature often focuses on discussing statutory provisions prescribing capital crimes without engaging in a deeper, foundational, and theoretical inquiry of the problem. Vietnamese literature at times simply lists the provisions on specific capital crimes and analyzes them using black letter rules $[17,18]$. This leaves a number of issues unexplored and unresolved, especially the ideological, political, cultural, and economic perspectives. English literature, in contrast, is much more nuanced and comprehensive when criticizing the problem [9,19-23]. However, English literature is unfortunately outdated when applied to newly promulgated provisions in Vietnam, most notably the 2015 Criminal Code, as amended in 2017. Much of the English literature approaches the problem from different perspectives, such as comparative law or anthropology with a well, narrowly framed research question. The scope of many English articles is unfortunately set in the context of drug-related crime with a narrow focus. 
This paper aims to provide a critical analysis of the changing nature of the death penalty in Vietnam from historical and legal perspectives with a focus on modern era's laws and practices ${ }^{1}$. Its main goals are to engage in and explore certain fundamental questions about the death penalty in different environments and circumstances, including its nature, role, and underlying criminal justice explanations throughout the history of Vietnam, as well as challenges that confront the efforts to understand more thoroughly and abolish the death penalty in the country. More specifically, it argues that the death penalty in Vietnam has transited from a tool of politics, a baseless use of force before 1986 to a manifestation of retributive justice in the modern time. As such, the paper will have four main sections with a special focus on contemporary time, its principal investigation's period. The second section focuses on exploring and analyzing the death penalty in the history of Vietnam where it was used as a tool of repression and control, the times of medieval, colonial and the period of war and socialist legality. Section 3 then proceeds to discuss the death penalty in the contemporary Vietnam, starting with the introduction of the 1985 Criminal Code all the way to the new 2015 criminal code when the theory of practice of human rights and retributive justice was introduced into Vietnamese law, hence providing a philosophical justification for the existence and application of the death penalty, especially since Vietnam ratified and applied several international human rights treaties among which the International Covenant on Civil and Political Rights is outstanding. The compliance can not only be found in the scholarly debate, but also on the law books where capital crimes are reduced and preserved for the worst of the worst offences. The adherence can also be found in practice through criminal procedure and execution where due process is required for the trial of capital crimes and more humane execution in the form of lethal injection is introduced to replace the firing squad. Section 4 will discuss challenges facing death penalty reform and the obstacles to the abolition of the death penalty in Vietnam. A key challenge is the rise of serious crimes that has led to a rise in the number of capital sentences given by the courts. The second obstacle is public support and secrecy surrounding the issue. These, in effect, create a dilemma situation where capital crimes are reduced but capital executions seem to increase, which is discussed in Section 5 within the concluding remarks.

As such, our key message in this first paper is that the nature of the death penalty has changed from a tool of power and coercion to a manifestation of justice based on the principles of human rights and rule of law. We hope that this will lay a foundation and more importantly the criteria for the discussions, debates, and assessments we will present in the second and third paper. In the second paper, we aim to rely on the arguments about the modern nature of the death penalty to critically assess the compliance and suitability of current capital offences, to see which capital offence meets the test of retributive justice and which does not. Based on that assessment, we will propose to eliminate non-compliance offences. The third paper will conduct a comparative study to compare the situations of the death penalty in Vietnam with other countries in similar conditions, such as development, urbanization. The comparative study expects to highlight similar conditions, criminal policy, criminal justice, laws, and responses different countries have chosen and to further understand their effectiveness. From that, we will also propose lessons learnt.

\section{Death Penalty in the History of Vietnam}

\subsection{Capital Punishment in Medieval Vietnam}

Law in Vietnam is historically comprised of written law (ius scriptum) and unwritten law (ius non scriptum) [23]. It is hard to determine when capital punishment has been laid down in Vietnamese

1 This article is an extensive revision and re-writing of the chapter titled "Capital Punishment in Vietnam: Status and Perspective" by Vu Cong Giao, one of co-authors of this article and published in Peter Hodgkinson (ed), Capital Punishment: New Perspectives; Ashgate: Surrey, UK, 2014. In this article, Vietnam means the Socialist Republic of Vietnam and its predecessor of the Democratic Republic of Vietnam, the nation-state that has control the northern part of Vietnam from 1945 to 1975 and from 1975 the entire territory. It excludes Republic of Vietnam another state that controlled the southern part of Vietnam from 1945 to 1975. 
unwritten law as available sources of relevant information are comparatively limited. However, as noted in some historical documents, capital punishment was applied heavily in the Dinh (968-980 AD) and early Le Dynasties (969-979 AD) with some extremely cruel forms, such as throwing criminals into tigers' and panthers' cages or into boiling cauldrons of oil [24,25].

It is widely accepted that Vietnamese written law was developed and enacted greatly in the Ly Dynasty (1009-1255 AD) in "Hinh Thu" (Penal Code) which consists of three volumes enacted under the order of King Ly Thai Tong in 1042. That Code was lost, and it is said that this Code specified the capital punishment, while others argue that the capital punishment was not applicable, at least for a certain period, when Buddhism was the national religion during the Ly Dynasty. If capital punishment was stipulated in the "Hinh Thu", such punishment would have been established in Vietnamese written law since the Ly Dynasty [24].

The Ly Dynasty was succeeded by the Tran Dynasty (1256-1417 AD). At that time, the two most important legal documents were 'Quoc Trieu Thong che' written under the order of King Tran Thai Tong in 1230, which consists of 20 volumes, and 'Hoang Trieu Dai Dien' written under the order of King Tran Du Tong in 1341. Both of the aforementioned codes stipulated capital punishment [26].

In the Le Dynasty (1418-1656 AD), there existed a renowned code on both the national and global scale, which is "Quoc Trieu Hinh Luat" (the National Penal Code), or "Bo luat Hong Duc" (Hong Duc Code) adopted under the order of King Le Thanh Tong (Hong Duc) in 1483. It consists of six volumes, 13 chapters, and 722 provisions. Each chapter regulates a group of social relations that share similar or the same nature that the sovereign deems important to be governed. What is of importance is that regardless of the nature of the social relation in question, it is all regulated by the threat of imposing a criminal punishment, in case it is violated, with the most severe one: Death. And the Code threatened people with 149 capital crimes out of 722 provisions. Although the code contains many provisions reflecting the ideas of humanity and the promotion of tolerance advanced by Confucianism, it also stipulated regulations on capital punishment [27].

Later on, as regards to the Nguyen Dynasty (1802-1945 AD), there existed an important but often criticized code, namely "Hoang Viet Luat le" (also known as Gia Long code), promulgated under the order of King Gia Long in 1815. It consists of 22 volumes and 398 provisions. This can be considered as the last code of the feudal regime in Vietnam and similar to the previous codes, it stipulated 105 crimes that can be given capital punishment [25].

In general, all aforementioned feudal codes follow the system of five penalties, including (1) "xuy" (flogging penalty), (2) "truong" (cudgel penalty), (3) “do" (servitude penalty), (4) "luu" (exile penalty), and (5) "tu" (capital punishment). The category/system of crimes for which capital punishment is applied varied in different dynasties. However, in general, capital punishment may be applied to a number of crimes and certain types of crimes were laid down in all codes for which capital punishment is applied. Those crimes included murder, high treason, receiving bribes, and embezzling property. Many forms of capital punishment enforcement were found to be cruel or vilely revengeful, such as "chu di tam toc" (three exterminations), slow slicing, mutilation, dismemberment, or quartering ... applied in accordance with the principles of "duc phat bat nhi bach"(punishing a person to warn others) or "dung hinh ky vu vo hinh "(stipulating the punishments so as not to be applied) [28]. Indeed, there are hundreds of capital crimes that can be found in The Le's Code of the fifteenth century or the Hoang Viet Luat Le of the Nguyen dynasty of the nineteenth century (it is even reported that in the Qing Dynasty of China, there were 800 capital crimes prescribed in its codes, [29]).

While this practice of heavy use of capital punishment can be said to be a normal phenomenon around the world and, in the case of East Asia, promoted by the typical legalism school of thoughts [29,30], the widespread and prevalence of capital crimes in medieval codes of law of Vietnam seems to contradict the country's own ideological and cultural foundation. Indeed, during a thousand years of the medieval period, Confucianism and Buddhism had together and by turn been the ideological orthodoxy of the country. Under these philosophies, it is believed that the foundation of a nation is based on morals, rituals, and ethics [31]. This belief derives from its core of humanism, 
which advances and promotes, among other things, Ren or benevolence [32]. Besides, Buddhism once the orthodox ideology of the government before being replaced by Confucianism, also teaches people to abstain from destruction of life [33]. In that context, one might expect that capital punishment and other forms of cruel treatment should have been rejected [27]. To the contrary, capital punishment was heavily applied and used by the government although some of the above Vietnam's feudal codes, especially "Hong Duc Code", also include regulations demonstrating the spirit of clemency and humanity to the criminals. Examples are regulations on pardon or commutation for those who plead guilty, or waiver, commutation or suspension of the penalty enforcement on women taking care of infants or people with mental illness or the elderly [26].

There are various explanations to this sharp contradiction. The first reason lies in the internal incoherence of these philosophies themselves. It has been argued that while promoting and advancing ideas of humanity, benevolence, non-violent treatment, both theories also contain language which might be interpreted to support the death penalty [34]. It leads to a second explanation that, especially attributable to Confucianism, although it promotes Ren in theory as a way of life and foundation of a harmonious society, in practice, to achieve that end, it emphasizes Ly or proper rite that people must observe in their daily life, the correct behavior and set of rules that they must follow in accordance with their position in various relationships. Any breach of Ly would be considered to threaten the order and proper working of society, and thus, deserves severe punishment. That is why law in medieval Vietnam and other Confucian-based society, such as China, is fundamentally penal, even when it deals with civil issues [35]. The third explanation is of practice, given the fact that all governments at that time were in the form of dynasty with absolute power, their main concern and goals were to hold on to power, repress any dissenting efforts, and punish political opposition, what mechanism would be more effective in achieving those ends than capital punishment. Thus, it is not surprising to find most of the provisions providing for capital crimes in the chapter prohibiting acts against the King and the Government.

Of practical importance, other reasons for the over-use of capital punishment can be attributable to the legal techniques used at the time. Influenced by the Chinese legal system, Vietnam did not know the distinction between civil and criminal law. In fact, all laws are criminal. It leads to a blind application of criminal penalties in general and capital punishment to all types of wrongs, regardless of them being civil or criminal, private or public. Thus, it is not uncommon to find in historical sources information that typical civil wrong, for example, theft of private property, can be served with a death penalty [36]. In the same vein, the criminal justice theory of Vietnam at the time did not classify crimes according to their seriousness, such as felony and misdemeanor, when each type would attract a different penalty. Instead, crimes are given punishment based on protected interests, such as the King, the Capital, or cattle. Thus, capital punishment application is not proportionate to the nature of the crime. That said, in medieval Vietnam, the death penalty hardly served any criminal justice purpose, it was a tool of the ruler to protect their regime in disguise of maintaining an orderly and stable society under a heavenly mandate.

\subsection{Capital Punishment in Colonial Vietnam}

This system of penal law upholding and spreading the death penalty lived on until the nineteenth century when France set their foot on the country. Under the French colonial ruling (1858-1945 AD), a new system of law was introduced into Vietnam: The civil law tradition. The arrival of a new legal system brings along its own idea of justice, especially criminal justice and death penalty perception [37]. Of the most relevant was the introduction of a new criminal justice system into Vietnam along with a distinction between civil law and criminal law. Hence, distinction between delicts or torts being a civil wrong from crimes which attract penal punishment, as well as the introduction of a new form of criminal law, a modern one based on the continental model [38].

Indeed, The French introduced to the Vietnamese a new concept of criminal justice based on the theory of punishment [39]. From this approach, punishment including the death penalty is justified 
from the idea of justice rather than an instrumental point of view [40]. Furthermore, the law is no longer criminal only. The classification of law into private and public on the one hand, and civil and criminal, on the other hand, is well-received [37]. Three different civil codes and three different criminal codes were codified and promulgated for three regions of Vietnam, namely Bac Ky (North Vietnam), Trung Ky (Central Vietnam), and Nam Ky (South Vietnam), so as to be appropriate to the political system of each region. Among the legal texts drafted by the French during this period, there were a few providing for capital punishment, in particular, the 1881 North Vietnam Penal Code (Hinh luat Bac Ky), dated 29 July 1881, the Decree dated 2 June 1932, the Decree dated 31 December 1937 and the Decree dated 23 June 1941 [41].

In addition, crimes are now classified in pursuant to their seriousness into three levels: Minor offences, serious offences, and grossly serious offences. Each type of offence will attract pre-determined, fixed types of penalties (Art 3, [42]). This classification guaranteed that minor offence would not be imposed a death penalty sentence. They were revolutionary ideas and contributed greatly to a new way of thinking and prescribing capital punishment. As a result, there was a plummet in the number of capital offences in the colonial criminal codes. Take, for example, the Hoang Viet Hinh Luat of 1933, there were only 18 capital offences provided for in the code, a remarkable change compared to the number in the medieval period. ${ }^{2}$ Later on, while the colonial government was overthrown and replaced by a national government in 1945, its legal system in general and criminal justice legacy still lived on until 1955 in the north and 1975 in the south of Vietnam.

Furthermore, this is also the period in which a game-changing factor in relation to capital punishment, which had emerged before was introduced in Vietnam. It is the formal acknowledgment and endorsement of the idea of individual rights and later human rights as natural, fundamental, and universal that all men regardless of race, social status, religion, ethnic shall enjoy. While the notion of human rights was symbolically endorsed with the promulgation of the Universal Declaration of Human Rights in 1948, many of its predecessors, including the two famous documents the Declaration of Independence of the United States of America in 1776 and the Declaration of the Rights of Man and of the Citizen of France in 1789, had been transplanted into Vietnam well before 1948. Ho Chi Minh even cited the rights and liberties endorsed in the Declaration of Independence of the United States of America in his famous 1945 Declaration of Independence as the foundation of a just and equal government [43]. Not only did these documents prove instrumental and influential later in the discussion for and against capital punishment internationally but also domestically for decades to come, it also did lay the foundation for the establishment of a national, independent government in 1945. This factor would re-emerge to shape Vietnam's understanding and debate about capital punishment in the late twentieth century.

\subsection{Capital Punishment in Socialist Vietnam}

While on the course of development, the colonial criminal justice system was hit by a rupture. The August 1945 Revolution lead by Ho Chi Minh and his Communist Party overthrew both the colonial and monarchical administration and founded a new country of Vietnam, which is independent from foreign colonial rule and pursuing the democratic republic system with the view towards building socialism in Vietnam. However, the war soon erupted between the new government and the old forces and lasted more than 30 years. These events make the issues of the death penalty become rather complex during the wartime.

At the outset, it should be noted that the right to life took a leading position in Ho Chi Minh's famous Declaration of Independence read in 1945. Quoting the American Declaration of Independence, Ho Chi Minh made clear that the right to life, liberty and pursuit of happiness was the cornerstone of a just and legitimate regime, including its law [44]. And indeed, a set of human rights was

2 This number is based on the calculation of the authors of this article. 
constitutionalized in the 1946 Constitution, setting a solid ground for a new, progressive criminal justice system. However, the list of constitutional human rights did not include the most important one, the right to life, ([45], Chapter 2 on the rights and duties of citizens) thus, lacking one of the most important constitutional limitations on the death penalty. Moreover, the role of the death penalty was even consolidated further by the fact that Vietnam was now facing the demands of war while at the same time resolutely trying to combat and eliminate counterrevolutionary elements and bourgeois class in order to build a dictatorship of the proletariat. As a result, these conditions seemed to contribute to the proliferation of capital crimes in the period between 1945 and 1985.

Compared to the colonial period, from 1945 to 1959, there were roughly 53 capital offences prescribed in a wide range of legal instruments, mostly executive. ${ }^{3}$ From 1959 to 1985 , the number decreased to 35 due to the suspension of colonial law. With the adoption of the 1985 Criminal Code, the number rose again to 44 crimes facing the death penalty.

The reasons for the increase in capital offences between 1945 and 1959, to our argument, can be blamed on the retention of colonial law on the one hand and the adoption of new crimes on the other hand. Indeed, the newly-created government understood that there could not be 'one day without law' [46]. For that strategic reason, the government chose to retain the old regime's legal system [47]. On 10 October 1945, president Ho Chi Minh issued Decree No.47 to retain in force all laws which had been issued previously and were still in effect at the time of the issuance of Decree No.47. Article 1 of the said decree reads as follows: 'Until new, uniform laws have been promulgated for entire Vietnam, all current laws of Tonkin, Annam, and Cochin-china remain in force if they do not violate provisions laid down in this decree' (Art 1, [47]). Article 12 went further in stipulating conditions for the continuous application of the old laws by stating that 'provisions provided in the old laws are to be applied only if they are not harmful to the independence of Vietnam and to the republic democratic regime' (Art 12, [47]). This decree was then amended twice. A minor amendment occurred in November 1945 to clarify which procedural codes should be kept and applied [48]. A second, more significant revision was implemented five years later when a list of thirteen new civil law principles was laid down contrary to which the old colonial civil codes were not to infringe or be applied [49]. Because of the effect of Decree No.47, all criminal codes which had been promulgated before remained in effect including their capital offences.

On the other hand, the new government was very responsive to the brake-out of a new war with the old enemy. Therefore, in order to reinstate and reinforce its efforts, as well as chances of victory, it resorted to the capital punishment as an effective means of control and suppression mostly to its own forces and the population under its authority. During this period, there were thirteen legal instruments providing thirty-five new capital offences. ${ }^{4}$ These capital offences were mostly tried by a new system of courts in which the military court played a key role. Among the aforementioned, Decree No.33C of 1945 provided that military courts had the jurisdiction to pronounce sentence and enforce sanctions imposed on those who carried out actions impairing the independence of the Democratic Republic of Vietnam (except for soldiers to whom military law should be applied). This suggests that the death penalty in the early period of the new government was fundamentally instrumental, being the tool of the government rather than serving any criminal justice purposes. This attestation is upheld further by another strong evidence which was the establishment of a special court named Special People Court-Tòa án nhân dân đặc biệt. A court created to implement the land reform program which aimed at eliminating the landlords and bourgeois class (Art 11, [50]). This special court had a wide range of discretions, including imposing the death penalty [51,52]. However, the number of capital offences reduced significantly after 1959, not because of the change in the policy of the government towards

3 This number is representative in the sense that it is not precise. The number is based on the number of capital offences provided for in the Hoang Viet Hinh Luat of 1933 plus subsequent capital offences prescribed by the Democratic Republic of Vietnam after 1945 and collected by the authors of this article.

4 This number is based on the survey of the authors of this article using various sources. 
the death penalty but due to the fact that in 1955 and again in 1959, laws which had been enacted during the colonial period were repealed entirely, including criminal laws [53,54]. In researching those documents, one can draw some conclusions as follows:

First, during this period, there was no single, codified legal instrument stipulating capital punishment and the system of penalties, specifically. Capital punishment was mentioned in various provisions issued in different years.

Second, capital punishment was not only reserved for crimes against national security, such as spying, rebellion, infringing upon territorial security, conducting banditry activities, defecting to the enemy or pursuing counter-revolutionary idea then fleeing from the country, it also applied to murder, intentionally inflicting injury on or causing harm to the health of other persons, detaining persons, threatening to murder for the purpose of counter-revolutionary, destroying, opposing or destroying the implementation of state policies, etc. Moreover, capital punishment was not clearly distinguished from administrative sanctions [38].

Third, the procedure for reviewing the death sentence was provided in the Law dated on 14 July 1960, requiring that death sentences must be reviewed by the plenary council of judges of the Supreme People's Court before execution. To be quorate, at least two-thirds of the judges of the Supreme People's Court must be in attendance of whom a simple majority is needed to approve the death sentence [55]. However, this provision could be impaired by another provision stipulating that the appeal court decision of other People's Courts, as well as the first-instance decision of the Supreme Court, was final and effective. That meant there was no appeal process. In case there was an appeal decision of lower courts or a first-instance decision of the Supreme Court sentencing the accused to death, he or she had no way to appeal against it (Art 9, [55]).

Fourth, the penal law, in general, and capital punishment, in particular, was modeled after other socialist criminal laws, mostly the Soviet Union. It did not only receive both the form and the substance of the law but also the historical-materialist ideology underpinned the adoption, interpretation, and application of the law [55].

The fourth reason implies a much bigger picture covering the issues such as nature, role and effect of crimes in general, and capital crimes in particular in a communism driven country. In one of the finest articles about the construction of socialist law in Vietnam, John Gillespie traces the theoretical root of its reception to the mention of the need to establish socialist law to a resolution of the Labor Party of Vietnam at its Second National Congress in 1951 [56]. Subsequently, a number of distinctive and fundamental principles representing the socialist law tradition began to be introduced. Among these were: (i) Socialist legality, the core notion of socialist law which was adopted officially by the Third National Congress of the Party in 1960, (ii) democratic centralism, an infamous Leninist notion, which was also introduced in the Second National Congress and written down in the 1959 constitution, (iii) collective mastery, a Chinese-inspired idea, which also emerged in the early 1950s through the writings of several Party and State leaders such as Prime Minister Pham Van Dong and Secretary General Le Duan [56].

Conditioned by this new ideology, perceptions about the role and nature of crimes and punishment were also re-aligned. In the place of the old colonial criminal justice theory were now the arguments about the withering away of state and crimes. However, before achieving that inevitable end, a harsher, stricter version of law and punishment needed to be put in place in order to successfully build socialism, and thus, move the country into communism [57]. It resulted in consolidation and reinforcement of criminal law and criminal penalties in Vietnam.

Therefore, unsurprisingly, in 1985, a new Penal Code, the first-ever comprehensive criminal code codified by the Socialist Republic of Vietnam was passed by the National Assembly on 27 June 1985 and entered into force on 1 January 1986. It comprised 20 chapters and 280 provisions. The adoption of the Code was a great landmark in the development of Vietnam's criminal law [51,52]. With regard to capital punishment, Article 27 of the 1985 Penal Code provided: 
Capital punishment is a special penalty applied to persons committing particularly serious crimes.

Capital punishment shall not apply to juvenile offenders and pregnant women at the time of committing crimes or being tried. Execution of capital punishment is postponed in the case of pregnant women or mothers of infants under 12-month old.

In cases where persons sentenced to death enjoy commutation, the capital punishment shall be converted into life imprisonment.

In the extraordinary case stipulated in a specific law, the execution may be carried out immediately following the trial.

Based on that provision, in the 1985 Penal Code, capital punishment was specified in 29 articles, accounting for $15 \%$ out of the total 195 articles on crimes. However, after four amendments, the number of articles providing for capital punishment in the 1985 Penal Code had increased dramatically as follows:

In 1989, the first amendment to the Code added four capital crimes concerning narcotics in Article 96(a);

In 1991, the second amendment to the Code added another three capital crimes relating to the infringement of socialist property rights;

In 1992, the third amendment to the Code added the capital crime of illegal cross-border transportation of goods and/or currencies (Article 97);

In 1997, the fourth amendment to the Code added another six capital crimes;

Accordingly, after four amendments, the 1985 Penal Code now specified 44 capital crimes accounting for $20.5 \%$ of the total 216 provisions (See Table 1 ).

This unusual increase and consolidation of capital crimes in the 1985 Penal Code and subsequent amendments are still hard to explain internally. It is even more difficult to comprehend when it comes to the fact that the death penalty applies to almost all types of crimes, even crimes infringing property prescribed in the Code [58]. Indeed, there is one observation that the 1985 Penal Code of Vietnam provides for more criminal offences than those of other socialist states [38]. John Quigley offers some reasons to the severity of the punishment threatened by the Code. It is largely due to the country's own economic, political condition, and legal culture at that time. Quigley cited former justice minister Phan Hien in laying six reasons for the increase in crime, and thus the code's severity: (1) The final show of resistance by the toppled exploiting classes, (2) acts of sabotage by the imperialists and other international reactionary powers, (3) the influences of bourgeois and other non-proletarian ideas, (4) shortcomings in one aspect or another of the management of the country, (5) the failure of the system of law to keep pace with socio-economic developments at some times and places, and (6) shortcomings in crime prevention [38].

In addition, the very fact that a Penal Code was chosen with very strict and severe punishments to be adopted as the first codified code of the Socialist Republic of Vietnam before other codes, such as civil or economic, speaks volume about the country's past legacy, most prominently the influence of Confucianism $[14,26,28]$. Thousand years of constantly using penal code as the main and only form of law, being the main tool of the government had left a strong imprint on the country and mindset of even the new socialist leadership. Penal law with a lot of provisions on criminal offences was considered to be the best way to maintain society's order and deter anyone who dared to go against socialist regime. In this way, the over-use of criminal offences in the 1985 Penal Code did not only reflect Vietnam's own policies of employing capital crimes. It also goes hand in hand with contemporary underlying arguments of proponents of the death penalty [59]. 
Table 1. Capital Crimes in the 1985, 1999 and 2015 Criminal Code.

\begin{tabular}{|c|c|c|c|c|c|c|}
\hline \multirow[b]{2}{*}{ Number } & \multicolumn{2}{|r|}{ The 1985 Criminal Code } & \multicolumn{2}{|r|}{ The 1999 Criminal Code } & \multicolumn{2}{|c|}{ The 2015 Criminal Code } \\
\hline & Provision & Crimes with Capital Punishment & Provision & Crimes with Capital Punishment & Provision & Crimes with Capital Punishment \\
\hline 1 & $72(1)$ & High treason & $78(1)$ & High treason & $108(1)$ & High treason \\
\hline 2 & $73(1)$ & $\begin{array}{c}\text { Carrying out activities aimed at } \\
\text { overthrowing the } \\
\text { People's administration }\end{array}$ & $79(1)$ & $\begin{array}{l}\text { Carrying out activities aimed at } \\
\text { overthrowing the } \\
\text { people's administration }\end{array}$ & $109(1)$ & $\begin{array}{c}\text { Carrying out activities aimed at } \\
\text { overthrowing the } \\
\text { People's administration }\end{array}$ \\
\hline 3 & $74(1)$ & Spying & $80(1)$ & Spying & $110(1)$ & Spying \\
\hline 4 & $75(1)$ & Infringing upon territorial security & $82(1)$ & Rebellion & $112(1)$ & Rebellion \\
\hline 5 & $76(1)$ & Rebellion & $83(1)$ & Banditry & $113(1)$ & $\begin{array}{c}\text { Terrorism against } \\
\text { people government }\end{array}$ \\
\hline 6 & $77(1)$ & Banditry & $84(1)$ & Terrorism & $114(10)$ & $\begin{array}{c}\text { Sabotaging the material-technical } \\
\text { foundations of the Socialist } \\
\text { Republic of Vietnam }\end{array}$ \\
\hline 7 & $78(1)$ & Terrorism & $85(1)$ & $\begin{array}{l}\text { Sabotaging the material-technical } \\
\text { foundations of the Socialist } \\
\text { Republic of Vietnam }\end{array}$ & $123(1)$ & Murder \\
\hline 8 & $79(1)$ & $\begin{array}{l}\text { Sabotaging the material-technical } \\
\text { foundations of the Socialist Republic } \\
\text { of Vietnam }\end{array}$ & $93(1)$ & Murder & $142(3)$ & Rape against children \\
\hline 9 & $84(1)$ & Destroying detention camps & $112(3,4)$ & Rape against children & $194(4)$ & $\begin{array}{c}\text { Manufacturing and/or trading in } \\
\text { fake goods being food, foodstuffs, } \\
\text { curative medicines, } \\
\text { preventive medicines }\end{array}$ \\
\hline 10 & $87(1)$ & Hijacking aircraft, ships & $133(4)$ & Plundering property & $248(4)$ & Illegally producing narcotics \\
\hline 11 & $94(2)$ & $\begin{array}{l}\text { Destroying important national } \\
\text { security works and/or facilities }\end{array}$ & $157(4)$ & $\begin{array}{l}\text { Manufacturing and/or trading in } \\
\text { fake goods being food, foodstuffs, } \\
\text { curative medicines, } \\
\text { preventive medicines }\end{array}$ & $250(4)$ & Illegally transporting narcotics \\
\hline 12 & 97 & $\begin{array}{l}\text { Illegal cross-border transportation of } \\
\text { goods and/or currencies }\end{array}$ & $193(4)$ & Illegally producing narcotics & $251(4)$ & Illegally trading in narcotics \\
\hline
\end{tabular}


Table 1. Cont.

\begin{tabular}{|c|c|c|c|c|c|c|}
\hline \multirow[b]{2}{*}{ Number } & \multicolumn{2}{|r|}{ The 1985 Criminal Code } & \multicolumn{2}{|r|}{ The 1999 Criminal Code } & \multicolumn{2}{|r|}{ The 2015 Criminal Code } \\
\hline & Provision & Crimes with Capital Punishment & Provision & Crimes with Capital Punishment & Provision & Crimes with Capital Punishment \\
\hline 13 & $95(3)$ & $\begin{array}{l}\text { Illegally manufacturing, stockpiling, } \\
\text { transporting, using, trading in or } \\
\text { appropriating military weapons } \\
\text { and/or technical means }\end{array}$ & $194(4)$ & $\begin{array}{l}\text { Illegally stockpiling, transporting, } \\
\text { trading in or } \\
\text { appropriating narcotics }\end{array}$ & $299(1)$ & Terrorism \\
\hline 14 & $98(2)$ & $\begin{array}{l}\text { Making, storing, transporting, } \\
\text { circulating counterfeit banknotes, } \\
\text { cheques, bonds, and } \\
\text { destroying currency }\end{array}$ & $231(2)$ & $\begin{array}{l}\text { Destroying important national } \\
\text { security works and/or facilities }\end{array}$ & $353(4)$ & Embezzling property \\
\hline 15 & $101(1)$ & Murder & $278(4)$ & Embezzling property & $353(4)$ & Receiving bribes \\
\hline 16 & $112(3)$ & Rape & $279(4)$ & Receiving bribes & $421(1)$ & $\begin{array}{l}\text { Undermining peace, provoking } \\
\text { aggressive wars }\end{array}$ \\
\hline 17 & $112(4)$ & Rape against children & $316(4)$ & Disobeying orders & $422(1)$ & Crimes against mankind \\
\hline 18 & $129(2)$ & $\begin{array}{l}\text { Plundering the property of the } \\
\text { Socialist Republic of Vietnam }\end{array}$ & $322(3)$ & Surrendering to the enemy & $423(1)$ & War crimes \\
\hline 19 & $132(3)$ & $\begin{array}{l}\text { Stealing property of the Socialist } \\
\text { Republic of Vietnam }\end{array}$ & 341 & \multicolumn{3}{|c|}{ Undermining peace, provoking aggressive wars } \\
\hline 20 & $133(3)$ & $\begin{array}{l}\text { Embezzling property of the Socialist } \\
\text { Republic of Vietnam }\end{array}$ & 342 & \multicolumn{3}{|c|}{ Crimes against mankind } \\
\hline 21 & 134 & $\begin{array}{l}\text { Appropriating property of the } \\
\text { Socialist Republic of Vietnam } \\
\text { through swindling }\end{array}$ & 343 & \multicolumn{3}{|c|}{ War crimes } \\
\hline 22 & $134(\mathrm{a})$ & \multicolumn{5}{|c|}{ Abusing positions and/or powers to appropriate property of the Socialist Republic of Vietnam } \\
\hline 23 & $138(3)$ & \multicolumn{5}{|c|}{ Destroying or deliberately damaging property of the Socialist Republic of Vietnam } \\
\hline 24 & $151(2)$ & \multicolumn{5}{|c|}{ Plundering civil property } \\
\hline 25 & 156 & \multicolumn{5}{|c|}{ Abusing positions and/or powers to appropriate civil property } \\
\hline
\end{tabular}


Table 1. Cont.

\begin{tabular}{|c|c|c|c|c|c|c|}
\hline \multirow[b]{2}{*}{ Number } & \multicolumn{2}{|r|}{ The 1985 Criminal Code } & \multicolumn{2}{|c|}{ The 1999 Criminal Code } & \multicolumn{2}{|c|}{ The 2015 Criminal Code } \\
\hline & Provision & Crimes with Capital Punishment & Provision & Crimes with Capital Punishment & Provision & Crimes with Capital Punishment \\
\hline 26 & 157 & \multicolumn{5}{|c|}{ Appropriating civil property through swindling } \\
\hline 27 & $167(3)$ & \multicolumn{5}{|c|}{ Producing and/or trading fake goods } \\
\hline 28 & $185(b)$ & \multicolumn{5}{|c|}{ Illegally producing narcotics } \\
\hline 29 & $185(\mathrm{c})$ & \multicolumn{5}{|c|}{ Illegally stockpiling narcotics } \\
\hline 30 & $185(\mathrm{~d})$ & \multicolumn{5}{|c|}{ Illegally transporting narcotics } \\
\hline 31 & $185(\mathrm{~d})$ & \multicolumn{5}{|c|}{ Illegally trading narcotics } \\
\hline 32 & $185(\mathrm{e})$ & \multicolumn{5}{|c|}{ Illegally appropriating narcotics } \\
\hline 33 & 185 (i) & \multicolumn{5}{|c|}{ Organizing the illegal use of narcotics } \\
\hline 34 & $185(\mathrm{~m})$ & \multicolumn{5}{|c|}{ Forcing, inducing other persons into illegal use of narcotics } \\
\hline 35 & 226 & \multicolumn{5}{|c|}{ Receiving bribes } \\
\hline 36 & 227 & \multicolumn{5}{|c|}{ Giving bribes, mediating bribes } \\
\hline 37 & 250 & \multicolumn{5}{|c|}{ Disobeying orders } \\
\hline 38 & 256 & \multicolumn{5}{|c|}{ Surrendering to the enemy } \\
\hline 39 & 257 & \multicolumn{5}{|c|}{ Abandoning combat positions } \\
\hline 40 & 269 & \multicolumn{5}{|c|}{ Destroying military weapons, technical means } \\
\hline 41 & 277 & \multicolumn{5}{|c|}{ Undermining peace, provoking aggressive wars } \\
\hline 42 & 278 & \multicolumn{5}{|c|}{ Crimes against mankind } \\
\hline 43 & 279 & \multicolumn{5}{|c|}{ War crimes } \\
\hline 44 & 280 & \multicolumn{5}{|c|}{ Recruiting mercenaries or working as mercenaries } \\
\hline
\end{tabular}




\section{The Changing Nature of the Death Penalty in Contemporary Vietnam}

In 2009, Johnson and Zimring made an observation about the death penalty in Vietnam in their renowned work which reads:

In Vietnam, the result is a contemporary death penalty system that in several central respects looks a lot like China's, with high levels of execution, a wide range of capital offenses, heavy reliance on confessions, few due process protections, strict control of death penalty information, little public criticism of the party-state's policy, and a leading role for the Communist Party in capital punishment policy-making [9].

Some observations still bear strong imprints on current laws and practices, but many others have changed since. At the same time of the adoption of the 1985 Criminal Code, another important event also took place which promised to change the course and perceptions about crimes and capital punishment in Vietnam again. That was the official endorsement of a series of reform initiatives known as Đổi Mới in 1986. Initially, these initiatives aimed at reforming the economy and economic management only. However, gradually and subsequently, the political and legal system was also not immune to the demands of reform and of a new era [60-62]. Market economy replaces centrally planned model, rule of law substitutes the dictatorship of the proletariat and natural law, human rights and criminal justice take the position of socialist legality and of class struggle. Criminal law was going to be given a new theoretical foundation which had a profound impact on the capital offences. Two new Criminal Codes were subsequently promulgated in 1999 and 2015, which saw a significant decline in the number of capital offences.

The decrease of the capital offences can also be attributable to another which is the rise of a criminal justice system based on the ideas of human rights. The new framework requires the respect and protection of the right to life. In addition, it is observable that a wide range of new theories of punishment is also finding its way into Vietnam and influences the perception of the people, especially legal scholars and law-makers, about the death penalty.

Doi Moi or Renovation also led to the integration of Vietnam into international communities where Vietnam would be required to play by international laws and standards, including international movement on death penalty abolition. Indeed, international relations have created another constraint on Vietnam's death penalty law and practice $[9,21,22]$. In relation to death penalty laws, from the early 1980s, Vietnam started to ratify and join seven key international instruments on human rights, including International Covenant on Civil and Political Rights (ICCPR) in 1982 and International Covenant on Economic, Social and Cultural Rights, also in 1982, United Nations Convention against Torture and Other Cruel, Inhuman or Degrading Treatment or Punishment in 2015 just to name a few. These backbone international human rights treaties, especially ICCPR, require member states to respect the right to life as the most precious right that a man shall enjoy and hence limits the use of the death penalty [63-65]. These instruments also set forth strict conditions for the limitations of human rights in special circumstances. In addition, these international human rights treaties also establish a committee of experts of its own to oversee the implementation of the treaty provision by member states. Some require member states to submit their compliance report for a certain period such as that of ICCPR. Since the time of ratification, Vietnam has submitted three national reports of ICCPR in 1990, 2002, and 2017. Therefore, the right to life started to gain momentum in the Vietnamese legal community. The right was constitutionalized for the first time in the 1980 Constitution. It has been then further reinforced and reinstated in the 1992 and 2013 Constitution. The 2013 Constitution also for the first time sets out a provision allowing legitimate limitations of human rights in Vietnam in a very limited number of situations (Art 14(2) [66]) and reinstate the idea that human rights, in general, and the right to life, in particular, are universal and most fundamental [67-69]. Other statutory provisions are also enacted or amended to protect the right to life, for example, the 2015 Civil Code, limiting the application of the death penalty in the 2015 Criminal Code, the protection of due process in criminal proceedings, and the more humane method of capital execution in the criminal execution law [70]. In 
practice, the death penalty is also one of the most heated issues for which Vietnam has consistently faced criticism and received recommendations for reform from international communities. In fact, Vietnam has tried to accommodate international requests and criticism through its reform of law and practice of the death penalty. Of the most prime example, it is of no surprise to find out that some of the significant changes in the attitude and practice of the death penalty in Vietnam are in line with the continuous participations of Vietnam in the Universal Periodic Review. Since 2009, Vietnam has attended three circles of the Universal Periodic Review in 2009, 2014, and 2019. Moreover, every time Vietnam attends, death penalty laws and practices are always the issues that receive the largest number of questions, recommendations, and actions that the country did try to address [71,72]. In the Addendum of the third circle of the Universal Periodic Review, Vietnam did accept in part a recommendation related to the death penalty in which Vietnam promises to "Ensure that the death penalty does not apply to offences other than the 'most serious' crimes, in accordance with the International Covenant on Civil and Political Rights" [71].

In addition, new theories about punishment and the death penalty are also introduced to Vietnam, triggering a new, lively debate about the necessity, nature, role, effectiveness of this cruelest and severe punishment. Punishment is no longer considered to be a tool at the disposal of the government to oppress the bourgeois class and reactionary elements, they now serve the purposes of retributive justice and deterrence [73-76]. Although many legal scholars still prefer retention of the death penalty to the abolition, the reception of new thoughts and heated debate about them still bring about positive and progressive changes in reducing the number of capital crimes to 18 in the 2015 Criminal Code [73].

\subsection{The Scope of the Death Penalty in Vietnam 1999 and 2015 Criminal Code}

The 1999 Penal Code was passed by the National Assembly of the Socialist Republic of Vietnam on 12 December 1999 replacing the 1985 Penal Code. The 1999 Penal Code was comprised of 24 chapters and 267 provisions amongst which were 29 articles stipulating capital punishment, which accounted for $11 \%$ of the total articles on crimes. Article 35 of the 1999 Penal Code provided that:

Capital punishment is a special penalty only applied to persons committing particularly serious crimes.

Capital punishment shall not apply to juvenile offenders, pregnant women and women nursing children under 36 months old at the time of committing crimes or being tried.

Capital punishment shall not apply to pregnant women and women nursing their children under 36 months old. For these cases, capital punishment shall be converted into life imprisonment.

In cases where persons sentenced to death enjoy commutation, the punishment shall be converted into life imprisonment.

Comparing the capital crimes in the 1985 Penal Code with the 1999 penal Code one can see that: First, with regard to definition, the forms of capital punishment's definition provided in the 1985 Penal Code and 1999 Penal Code are similar. However, regarding the criteria for application, there are significant differences, as described in Table 2: 
Table 2. Criteria for applying the death penalty.

\begin{tabular}{|c|c|c|c|}
\hline Criteria & $\begin{array}{c}\text { Article } 27 \text { of the } 1985 \text { Penal } \\
\text { Code }\end{array}$ & $\begin{array}{c}\text { Article } 35 \text { of the } 1999 \text { Penal } \\
\text { Code }\end{array}$ & The 2015 Penal Code \\
\hline $\begin{array}{l}\text { The scope of } \\
\text { application }\end{array}$ & $\begin{array}{l}\text { Serious crimes (minimum } \\
\text { sentence of five years } \\
\text { imprisonment) }\end{array}$ & $\begin{array}{l}\text { Particularly serious crimes } \\
\text { (minimum sentence fifteen } \\
\text { years imprisonment) }\end{array}$ & $\begin{array}{l}\text { Particularly serious crimes } \\
\text { (minimum sentence fifteen years } \\
\text { imprisonment) applicable to } \\
\text { crimes infringing national } \\
\text { security, individual life, crimes } \\
\text { in relation to narcotics, } \\
\text { embezzlement, and a limited } \\
\text { number of particularly serious } \\
\text { crimes prescribed by the } \\
\text { Penal Code. }\end{array}$ \\
\hline Inapplicable subjects & $\begin{array}{l}\text { Juvenile offenders, pregnant } \\
\text { women at the time of } \\
\text { committing crimes or } \\
\text { being tried. }\end{array}$ & $\begin{array}{l}\text { Juvenile offenders, pregnant } \\
\text { women, and women nursing } \\
\text { children under } 36 \text { months } \\
\text { old at the time of committing } \\
\text { crimes or being tried. }\end{array}$ & $\begin{array}{l}\text { Juvenile offenders, pregnant } \\
\text { women, and women nursing } \\
\text { children under } 36 \text { months old or } \\
\text { person above } 75 \text { years old at the } \\
\text { time of committing crimes or } \\
\text { being tried. }\end{array}$ \\
\hline $\begin{array}{l}\text { Reprieving and } \\
\text { commuting }\end{array}$ & $\begin{array}{l}\text { Capital punishment to } \\
\text { pregnant women and } \\
\text { women nursing their } \\
\text { children under } 36 \text { months } \\
\text { old shall be reprieved. }\end{array}$ & $\begin{array}{l}\text { Capital punishment shall not } \\
\text { apply to pregnant women } \\
\text { and women nursing their } \\
\text { children under } 36 \text { months } \\
\text { old. For these cases, capital } \\
\text { punishment shall be } \\
\text { converted into } \\
\text { life imprisonment. }\end{array}$ & $\begin{array}{l}\text { Juvenile offenders, pregnant } \\
\text { women, and women nursing } \\
\text { children under } 36 \text { months old } \\
\text { and person above } 75 \text { years old at } \\
\text { the time of committing crimes or } \\
\text { being tried. } \\
\text { Those who are imposed the } \\
\text { death penalty for having } \\
\text { committed the crime of } \\
\text { embezzlement, receiving bribes } \\
\text { but have returned three-fourths } \\
\text { of the embezzled property or } \\
\text { bribed property and cooperated } \\
\text { with competent authorities in } \\
\text { discovering, investigating and } \\
\text { handling the crime. }\end{array}$ \\
\hline $\begin{array}{l}\text { Judgment-executing } \\
\text { immediately after the } \\
\text { Court's decision }\end{array}$ & $\begin{array}{l}\text { Provided that “ ... Death } \\
\text { sentence shall be executed } \\
\text { immediately after trial only } \\
\text { in special cases provided } \\
\text { separately by law" }\end{array}$ & $\begin{array}{l}\text { Remove the provision: “... } \\
\text { Death sentence shall be } \\
\text { executed immediately after } \\
\text { trial only in special cases } \\
\text { provided separately by law" }\end{array}$ & \\
\hline
\end{tabular}

Second, the number of capital crimes in the 1999 Penal Code $(29$ articles, accounting for $11 \%$ of the total articles) is much reduced compared to those in the 1985 Penal Code (44 articles, accounting for $20.5 \%$ of the total articles).

Third, the 1999 Penal Code, which retains the crimes seriously endangering national security, experienced a significant decrease in the number of crimes relating to national security, which stood at an extremely high rate in the 1985 Penal Code. In addition, the proportion of narcotics-related capital crimes is also reduced in the 1999 Penal Code [68].

On 19 June 2009, the National Assembly's 12th Session voted to pass the Law amending and supplementing the Penal Code of 1999 (hereinafter the amended 1999 Penal Code). The majority of the legislators (64.5\%) approved the removal of capital punishment from a number of articles of the 1999 Penal Code namely (Source: [77]):

- $\quad$ Rape (Article 111)

- $\quad$ Appropriating property through swindling (Article 139)

- $\quad$ Smuggling (Article 153)

- $\quad$ Making, storing, transporting and/or circulating counterfeit money, treasury bills and/or bonds (Article 180)

- $\quad$ Organizing the illegal use of narcotics (Article 197) 
- $\quad$ Hijacking aircraft, ships (Article 221)

- $\quad$ Offering bribes (Article 289)

- Destroying military weapons, technical means (Article 334).

Nevertheless, the National Assembly neither approved nor passed the motion to separate the illegally stockpiling, transporting, trading in or appropriating narcotics capital crimes into the illegally stockpiling, transporting narcotics crimes (Article 194 (a)) and the trading in or appropriating narcotics (Article 194). The majority of the National Assembly delegates proposed to keep these provisions of the 1999 Penal Code, asserting that they are dangerous crimes, and moreover, the illegally trading in, transporting, stockpiling narcotics acts are closely linked with each other. In fact, these are the crimes, which figures indicate are on the increase and are highly dangerous. Thus, keeping capital punishment for these crimes is essential to deter, prevent, and strictly punish the criminals.

Later, the National Assembly passed the resolution on the implementation of the law amending and supplementing the Penal Code of 1999 with $88.44 \%$ votes in favor. Accordingly, the law came into force on 1 January 2010. Crimes stipulated in the law amending and supplementing the Penal Code of 1999 committed prior to 1 January 2010 stand as the 2010 legislation is not retroactive. In the event that the appeal relied on other bases or was lodged prior to 1 January 2010, the cassation review must be in conformity with point (b) and (d) of this clause [78]. When the law amending and supplementing the Penal Code of 1999 was promulgated, capital punishment did not apply to the illegal stockpiling, transporting narcotics criminals stipulated in Article 194(4) and criminals stipulated in Article 111(3), 139(4), 153(4), 180(3), 197(4), 221(3), 289(4) and 334(4) of the 1999 Penal Code. With regard to the criminals affected by this provision, they will have their sentences commuted by the People's Supreme Court President to life imprisonment (Art 1(2)(a) [78]).

Continuing with this trend, in 2015, a new Criminal Code was enacted. The new criminal code reduces further the number of crimes that are punished by death. The number now stands at 18 (See Table 1). The death penalty is now reserved for the worst types of crimes, mostly in relation to national security, murder, war crimes, crimes against mankind and drug-related crime. There are five conditions used to examine which crimes should or should not be punished by the death penalty. First is the importance of protected interests. Second is the nature, seriousness of the crime as well as personal conditions of the criminals. Third is the practical demands and needs to combat that crime. Fourth is the availability and effectiveness of other penalties other than capital punishment. And the fifth condition, the international trend in relation to the crime in question [79].

In addition, the conditions and criteria for imposing the death penalty are amended to exempt certain criminals from the list of being punished by death. Now, at the time of trial, juvenile offenders, pregnant women and women nursing children under 36 months old or people above 75 years old at the time of committing crimes cannot be given death sentences (Art 40(1), (2) [80]). They also shall not be executed if, at the time of execution, they belong to one of the above-mentioned groups (Art 40(3) [81]). Furthermore, those who are imposed the death penalty for having committed the crime of embezzlement, receiving bribes but have returned three fourths of the embezzled property or bribed property and cooperated with competent authorities in discovering, investigating, and handling the crime shall have their death penalty changed to life imprisonment (Art 40(3)(c) [80]).

\subsection{The Guarantee of Due Process, Pre-Trial and Fair Trial Rights in the Criminal Legal Procedures to Impose Capital Punishment in Vietnam}

One important issue relating to the death penalty is due process. That means capital punishment must be applied through a legally strict and transparent procedure. According to Article 268 of the 2015 Criminal Procedures Code of Vietnam, the courts competent to impose the death sentence are provincial courts. The Code also contains strict regulations of criminal cases with which the accused are prosecuted with capital crimes. In particular, the 2015 Criminal Procedures Code provides: 
With regard to defense counsel, pursuant to Article 76(1)(a), where the accused charged with offences punishable by death do not seek the assistance of defense counsel, the investigating bodies, procuracies or courts must request bar associations to assign law offices to appoint defense counsel for such persons or request the Vietnam Fatherland Front Committees or the Front's member organizations to appoint defense counsel for their organizations' members. However, the accused and their lawful representatives shall have the right to request a change of, or refuse to have, defense counsel. Pursuant to Article 291 governing the appearance of defense counsels, if defense counsel is absent, the courts shall still open the court sessions. Nevertheless, where defense counsel is compulsorily required under the provisions of Article 76 of this Code (the accused or defendants charged with capital crimes) but they are absent, the trial panels must postpone the court sessions (Art. 76(1)(a), Art.291(2), [81]).

As for the composition of first-instance trial panels, in compliance with Article 254, for cases where the defendants brought for the trial are charged with capital crimes the trial panel shall be composed of two judges and three jurors (Art. 254, [81]). Furthermore, in accordance with Article 350(1), governing serious and complicated cases, more than two procurators may together participate in court sessions with provision for alternate procurators (Art. 350(1), [81]).

In addition to these stipulations, the 2015 Criminal Procedures Code contains strict procedures for consideration of death sentences before execution and execution of capital punishment (Article 367). Pursuant to those articles, within seven days after the judgments become effective, the condemned may lodge amnesty petitions to the State President and where convicts have petitioned for commutation, the death penalty shall be executed only after the State President rejects their petitions (Art. 367, [81]).

On the right to appeal, according to Article 27 and 61(2)(m) of the 2015 Criminal Procedures Code of Vietnam, in any criminal cases, the accused has the right to appeal to the upper court. Articles 332 and 333 of the Code state that the appeal must be either submitted to the court of first instance or the court of appeal within 15 days of being sentenced to death. Article 335 provides that a late appeal might be accepted if the accused can show good cause. The court of first instance has to transfer the case to upper court for rehearing within seven days of the appeal being lodged (Article 338) and Article 346 requires that the court of appeal has to review (open the appeal trial) within 90 days of the appeal being lodged (Art. 338, 346, [81]). Since basically, Vietnam criminal procedure follows the civil law tradition, the issue of mandatory capital punishment does not arise in the country.

The most frequently used mode of execution in feudal times was decapitation (by knife or sword), whilst during the French colonial period, the guillotine was the most popular method. Following independence in 1945, the Democratic Republic of Vietnam decided to change to execution by firing squad. However, during two wars of resistance against France and the United States of America enemy combatants were executed, extra-judicially, by a dagger, sword, knife, mine, grenade, bows and arrows, trap or poison, etc. However, lawful executions were by firing squad as required by Art 259(3) Criminal Procedure Code of Vietnam of 2003: "The death sentence is executed by shooting (firing squad)". Nevertheless, the Law on Criminal Execution of 2010 changed the method of execution for the death penalty to lethal injection (Art. 59(1), [82]). According to Degree 82/2011/NĐ-CP dated 19 September 2011, the firing squad has been replaced by the method of lethal injection since the 1 November 2011. The decision to change the method of execution to lethal injection, according to the government, is to cause less pain to offenders and to reduce the negative psychological impact on the executioners [83].

On the issue of extradition in capital cases, the 2015 Criminal Procedure Code of Vietnam stipulates only general principles about criminal extradition in order to examine penal liabilities or execute judgments but do not specifically refer to extradition in cases imposing capital punishment ([81], Chapter XXXV on International Cooperation in Criminal Matters). However, the Law on Mutual Legal Assistance of 2007 makes clear that the convict facing a death penalty can be extradited (Art 33(1), [84]).

According to Article 491(3), based on the international agreements which the Socialist Republic of Vietnam has signed or acceded to on the principle of reciprocity, the state may: (1) Request the 
foreign authorities with corresponding competence to extradite persons who are accused or convicted of criminal acts to be returned to the Socialist Republic of Vietnam for trial or sentence or to serve their penalty, (2) extradite foreigners who have committed criminal acts or convicted under legally valid judgments, from the territory of the Socialist Republic of Vietnam, to the requesting nations for trial or sentence or to serve their penalties (Art. 491(3), [81]).

Article 35 of the Law on Mutual Legal Assistance stipulates reasons for refusal of extradition, accordingly, the bodies with procedure-conducting competence of the Socialist Republic of Vietnam may refuse to extradite persons in one of the following cases: (a) The person for whom extradition is requested is citizen of the Socialist Republic of Vietnam, (b) where the statute of limitations has expired, (c) where the person[s] have already been convicted by the courts of the Socialist Republic of Vietnam for the crimes stated in the extradition request or have ceased under the provisions of this Code, (d) the persons have sought refuge in Vietnam through fear of cruel, inhuman, and degrading treatment in the requesting country (Art. 35(1), [84]).

Pursuant to Article 35(2) of the same act, the state agency with procedure-conducting competence of the Socialist Republic of Vietnam may also refuse to extradite in one of the following cases: (a) Under the criminal legislation of the Socialist Republic of Vietnam, the acts taken by the persons requested to be extradited do not constitute offences, (b) the persons requested to be extradited are being examined for penal liability in Vietnam for the acts stated in the extradition requests (Art. 35(2), [84]).

\subsection{The More Humane Execution of Capital Punishment in Vietnam}

For those who have been convicted with the death penalty and the decision has come into effect, they now face the possibility of having the decision executed. The execution of the death penalty means taking of the convict's life (Art 3(4), [82]). Because of its extreme severity, the execution must be precautious and follow strict legal proceedings required by laws.

As presented above, the 2015 Criminal Procedures Code stipulates some related regulations and procedures in Chapter XXIV, which include provisions on procedures for consideration of death judgments before execution and execution of capital punishment (Article 367).

Pursuant to Article 367, the consideration of death judgments before execution is conducted in accordance with the following process and procedures:

After the death judgments become legally valid, the files are sent to the President of the Supreme People's Court and the Chairman of the Supreme People's Procuracy. Within two months of receiving the judgments and case files, decisions have to be made whether or not to challenge the judgments. If the judgments are confirmed the condemned has seven days to send amnesty petitions to the State President.

In the event the conviction and sentence are not confirmed the Supreme People's Court must immediately notify the condemned so that the latter can make petitions for commutation of their death penalties. Only when these petitions are rejected by the State President can the execution proceed (Art 258, [81]). However, for those convicts who meet the conditions prescribed at Article 40 (3) of the 2015 Criminal Code, they will have their death penalty commuted to life imprisonment (Art. 367(2), [80]).

Pursuant to the Law on Criminal Execution of 2010, executions shall comply with the following process and procedures:

The presidents of the courts which have conducted first-instance trials are authorized to issue execution decisions and set up the councils for execution, each consisting of representatives of the court, procuracy, and police. The judgment-executing councils must check the identity cards of the condemned before executing the judgments. Where the condemned are women, before issuing decisions to execute the judgments, the presidents of the first instance courts must examine the conditions for non-application of capital punishment, prescribed in Article 40 of the Penal Code. If there are grounds that the condemned meet the conditions prescribed in Article 40 of the Penal Code, the presidents of the first instance courts will inform the President of the Supreme People's Court for 
consideration and commutation of the capital punishment to life imprisonment. Before executing women, the judgment-executing councils shall, apart from checking their identity cards, check the documents related to the conditions for non-application of the capital punishment prescribed in Article 40 of the Penal Code. Where the judgment-executing councils detect that they meet the conditions prescribed in Article 40 of the Penal Code, they shall postpone the execution and report such to the presidents of the first instance courts who will inform the President of the Supreme People's Court for consideration and commutation of the death sentence to life imprisonment (Art. 40, [80]).

Before the execution, the condemned must be given and read the decision to execute the judgments, the decision to confirm the judgment of the President of the Supreme People's Court and the Chairman of the Supreme People's Procuracy, and if they have made petitions for commutation they must be given and read the State President's decisions to reject their commutation petitions. Death penalties shall be executed by injecting lethal poison (Art. 59(1), [82]).

The execution of capital punishment must be recorded in writing which must clearly state the handing of decisions to the convicts for reading, their comments, and details of any correspondence and articles they may have left to their relatives.

In special circumstances, the judgment-executing councils shall postpone the execution and report such to the presidents of the courts which have issued the execution decisions for further reporting to the President of the Supreme People's Court (Art. 58, [82]).

In general, the above provisions relate to transparency and publicity in the application of the death penalty in Vietnam in conformity with relevant international standards. However, in this area, one aspect of transparency is that all information regarding the application of capital punishment in the country should be recorded on an annual basis, this remains a very controversial topic globally as such disclosure is recognized as a state obligation in the area of human rights. Historically, Vietnam has disclosed execution but in recent years (see Table 3), this practice has been terminated, which is why there are no accurate figures about numbers of executions in Vietnam in recent years (however, some unofficial information was leaked from different resources. For example, according to a local online newspaper (An Ninh Thu Do, or Security of the Capital-governed by Police Agency of Hanoi), the number of prisoners waiting for execution in Vietnam as of December 2011 is 360 persons, [85]). Nevertheless, the Government is reconsidering its decision not to disclose this information.

Table 3. Death penalty application in Vietnam during 1992-2002. (Source: the Supreme People Court of Vietnam cited in [73]).

\begin{tabular}{ccccc}
\hline Year & $\begin{array}{c}\text { Total Number of } \\
\text { Defendants Who } \\
\text { Were Judged in the } \\
\text { Court of First } \\
\text { Criminal Judgment }\end{array}$ & $\begin{array}{c}\text { The Total Number } \\
\text { Defendants Who } \\
\text { Were Sentenced to } \\
\text { the Death Penalty }\end{array}$ & $\begin{array}{c}\text { \% of the Total } \\
\text { Number of } \\
\text { Defendants Who } \\
\text { Have Been Judged } \\
\text { to Those Given } \\
\text { the Death Penalty }\end{array}$ & $\begin{array}{c}\text { Specific Number of Defendant } \\
\text { Sentenced by the Death Penalty in } \\
\text { Four Separate Criminal Sanction } \\
\text { Groupings: Corruption(I), } \\
\text { Narcotics(II), Rape Against } \\
\text { Children(III), Felony Murder (IV) }\end{array}$ \\
\hline 1992 & 39,920 & 88 & 0.22 & 0.20 \\
\hline 1993 & 47,237 & 95 & 0.18 & 0.20 \\
\hline 1994 & 47,822 & 88 & 0.18 & Group I:7; Group II:26; \\
\hline 1995 & 51,757 & 104 & 0.38 & Group III:10; \\
\hline 1996 & 62,494 & 117 & & Group IV:118 \\
\hline 1997 & 42,440 & 162 & 0.26 & Group I:8; Group II:57; \\
\hline 1998 & 75,280 & 200 & Group III:7; Group IV:128 \\
\hline
\end{tabular}


Table 3. Cont

\begin{tabular}{ccccc}
\hline Year & $\begin{array}{c}\text { Total Number of } \\
\text { Defendants Who } \\
\text { Were Judged in the } \\
\text { Court of First } \\
\text { Criminal Judgment }\end{array}$ & $\begin{array}{c}\text { The Total Number } \\
\text { Defendants Who } \\
\text { Were Sentenced to } \\
\text { the Death Penalty }\end{array}$ & $\begin{array}{c}\text { \% of the Total } \\
\text { Number of } \\
\text { Defendants Who } \\
\text { Have Been Judged } \\
\text { to Those Given } \\
\text { the Death Penalty }\end{array}$ & $\begin{array}{c}\text { Specific Number of Defendant } \\
\text { Sentenced by the Death Penalty in } \\
\text { Four Separate Criminal Sanction } \\
\text { Groupings: Corruption(I), } \\
\text { Narcotics(II), Rape Against } \\
\text { Children(III), Felony Murder (IV) }\end{array}$ \\
\hline 1999 & 76,663 & 202 & 0.26 & $\begin{array}{c}\text { Group I:9; Group II:78; } \\
\text { Group III:5; Group IV:109 }\end{array}$ \\
\hline 2000 & 61,272 & 208 & 0.34 & $\begin{array}{c}\text { Group I:2; Group II:87; } \\
\text { Group III:9; Group IV:109 }\end{array}$ \\
\hline 2001 & 58,454 & 159 & 0.27 & Group II:60; Group III:3; Group IV: 90 \\
\hline 2002 & 62,264 & 140 & 0.22 & \\
\hline & Total: 625,603 & 1563 & 2.71 & \\
\hline
\end{tabular}

\section{The Obstacles to the Abolition of the Death Penalty in Vietnam}

\subsection{The Secrecy of the Death Penalty}

The first challenge facing the issue of the death penalty in Vietnam is a provision prohibiting the disclosure and release of information on the matter [86]. This information is deemed to be top secret and those who disclose it either intentionally or unintentionally shall be condemned by criminal penalties up to 15 years in prison (Art. 337, 338, [80]). This, in effect, renders all academic research, policy debate, and social discussion in relation to capital punishment void and dangerous in terms of legal consequences. It is not hard to find experts and scholars, when discussing the death penalty in Vietnam, discuss plainly related legislation or theory about the death penalty and avoid practical information or implications altogether (for example, Vu Thi Thuy makes clear about this intentional avoidance in her paper about the death penalty in Vietnam, [79]). As a consequence, the prohibition hinders the efforts in delivering a meaningful discussion about the death penalty in Vietnam, making it more difficult to fully understand underlying causes, as well as the broader circumstances surrounding the death penalty. This creates a dilemma situation and obstacle for any Vietnamese law-maker, policy-maker, law-enforcer or academic author who would want to discuss and solve the problems of the death penalty in Vietnam. In reality, quite a few people could gain access to primary data on the death penalty and understand its problem firsthand but are unable to discuss it in an open manner. This prohibits their meaningful engagement and contribution to the problems of the death penalty in the country. Most of the time, they have to rely on scare secondary, at times unverified, information that has been published by other sources as a way to overcome legal obstacles and protect their legal safety [87]. Much of the information that is going to be made available below is an example. The authors of this paper have no choice but to rely on other sources of data that have been thankfully and bravely published in other Vietnamese scholarly and academic publications or in foreign sources with one exception that is a rare public opinion survey conducted by the School of Law, Vietnam National University, Hanoi where the authors work. This challenge is not easy to be solved in the short term as data on the death penalty have been reinforced as a state secret in the 2018 Law on State Secret as part of the information on criminal execution.

\subsection{High Number of Capital Sentences}

The second challenging issue facing the death penalty discourse in Vietnam is the presumed high number of executions. Le Van Cam and Nguyen Thi Lan and Trinh Quoc Toan, in two of very rare studies cite a report of the Supreme Court of Vietnam and provide an overview of the actual death penalty application in Vietnam between 1992 and 2010 [17,18] (Table 3).

In a recent move, a number of domestic newspapers citing a report of the Ministry of Public Security, report that from August 2013 to 30 June 2016, there have been 429 executions [88]. Because 
of the number, Vietnam has attracted international criticism for its high number of executions, being accused of one of being the world's biggest executioners [5,89]. In practice, it is not difficult to find in a daily journalistic report news about death sentences given to the accused, sometimes even to a large group of defendants of five or eight people [90]. The fact that the Ministry of Public Security proposes to build five more capital execution centers worries not only domestic stakeholders but also the international community.

From the numbers made available in Table 4 above, while the number of capital crimes decreases, the number of capital sentences remains mostly unchanged. The number of capital sentences given by the first instance court for the period of 2001 to 2016 is almost equal to the number of capital sentences handed down by the first instance courts for the period of 1985 to 2000, while the capital crimes fell from 49 to 22. One of the reasons for the remaining high number of capital sentences throughout might be attributable to the rise of criminal activities in the country in the modern era. Other data published paints a dark picture of criminal activities, investigations, and trials in Vietnam from 1986 to 2008. The number of criminal trials increased year by year. For example, between 1986 and 1988 there were 66.986 first instance criminal trials. However, during the period of 2006 and 2008, there were 197.282 first instance criminal trials held, three times higher than the period of 1986-1988 [92]. Many terrible murder, rape or drug cases have been reported on national news outlets indicating that actual criminal offences are on the rise, hence the number of capital sentences. It is foreseeable that the situation cannot be expected to change soon in relation to the number of actual crimes.

Table 4. Combined number of death sentence between 1985 and 2016 [5,17,73,91].

\begin{tabular}{cccc}
\hline & 1985-2000 & 2001-2016 \\
\hline Law in effect & $\begin{array}{c}\text { Criminal Code of 1985 } \\
\text { (as amended in 1989, } \\
\text { 1991, 1992, 1997) }\end{array}$ & Criminal Code of 1999 (as amended in 2009) \\
\hline $\begin{array}{c}\text { Number of } \\
\text { capital crimes }\end{array}$ & $\begin{array}{c}\text { 44 out of 216 offences } \\
\text { account for 20,37\% of } \\
\text { total crimes }\end{array}$ & $\begin{array}{c}\text { 29 out of 264 offences account } \\
\text { for 11\% of total crimes }\end{array}$ & $\begin{array}{c}\text { 22 out of 266 offences account } \\
\text { for 8\% of total crimes }\end{array}$ \\
\hline $\begin{array}{c}\text { Number of } \\
\text { capital sentences }\end{array}$ & 2600 & Missing & 201055 \\
\hline $\begin{array}{c}\text { Number of } \\
\text { capital executions }\end{array}$ & Missing & & 1134 \\
\hline $\begin{array}{c}\text { Total criminal } \\
\text { sentences } \\
\begin{array}{c}\text { including capital } \\
\text { sentences) }\end{array}\end{array}$ & & & \\
\hline
\end{tabular}

\subsection{Public Opinion}

The third factor which should be taken into consideration is the impact of any of public opinion on the retention or abolition of the death penalty in Vietnam. While it has been shown that public opinion is not a barrier to the death penalty abolition worldwide, public opinion is a difficult variable in determining and applying the death penalty in Vietnam because it is often influenced by various different factors, such as psychological reaction, especially when a very serious crime is committed [90-93].

A recent survey conducted by the School of Law of the Vietnam National University, Hanoi, where the authors of this article also show that the public opinion on the abolition of capital punishment in Vietnam, is still conflicting, controversial, and hard to determine.

In total, as Table 5 demonstrates, 570 out of 1103 (51.68\%) respondents were opposed to capital punishment and the reasons why they support the death penalty abolition are shown in Table 6 below [94]: 
Table 5. Opinion on the death penalty of the first group. (The first group consisted of convicts who have been incarcerated in prison. In the survey, 587 questionnaires were distributed to convicts who received a termed imprisonment sentence in three different prisons in three separate provinces of Vietnam, including Thanh Hoa, Bac Giang, and Hanoi. Source: [94]).

\begin{tabular}{cccc}
\hline No. & Opinion & Number of Questionnaires & Proportion \\
\hline 1 & Should remove from punishment system & 222 & $37.82 \%$ \\
\hline 2 & Should restrict the application & 305 & $51.96 \%$ \\
\hline 3 & Should continue the penalty & 35 & $5.96 \%$ \\
\hline 4 & Other tendencies & 25 & $4.26 \%$ \\
\hline & Total & 587 & $100 \%$ \\
\hline
\end{tabular}

Table 6. Opinion on the death penalty of the second group. (The second group consisted of people who were randomly selected from the law and educational communities, including: (1) Law students, (2) official who work in state agencies of the judicial system, such as police, procuracy, and court officials, as well as from departments of judgment and execution, (3) people who work in law firms, (4) professors, and (5) from ten families who have had relatives sentenced to death by the death penalty after committing a particularly serious crime, which is defined in the Penal Code. The analysis of 516 general questionnaires which were distributed to these five types of people shows the results of their awareness in the four aspects below: Source: [94]).

\begin{tabular}{cccc}
\hline No. & Opinion & Number of Questionnaires & Proportion \\
\hline 1 & Should abolish the death penalty & 348 & $67.44 \%$ \\
\hline 2 & Should continue the death penalty & 168 & $32.56 \%$ \\
\hline & Total & 516 & $100 \%$ \\
\hline
\end{tabular}

In addition, the abovementioned survey also examined the opinions of 50 respondents regarding the deterrent effect of capital punishment. In this regard, the results are as follows (Table 7):

Table 7. Reasons for opposing the death penalty.

\begin{tabular}{cccc}
\hline No. & Reasons & Number of Questionnaires & Proportion \\
\hline 1 & $\begin{array}{c}\text { The nature of the death penalty is the most severe and } \\
\text { cruel punishment available. }\end{array}$ & 75 & $21.55 \%$ \\
\hline 2 & Life imprisonment is enough to punish convicts. & 141 & $40.52 \%$ \\
\hline 3 & Both of two reasons above. & 94 & $27.01 \%$ \\
\hline 4 & Vietnam rarely applies the death penalty in practice. & 23 & $6.61 \%$ \\
\hline 5 & Other opinion or those without an expressed reason. & 15 & $4.31 \%$ \\
\hline & Total & 348 & $100 \%$ \\
\hline
\end{tabular}

The survey results seem in line with other public opinion surveys in Vietnam. Vu Thi Thuy, in her own survey also reports that 91\% of respondents agree to keep the death penalty in 2006. This percentage rose to $94 \%$ in 2016 . However, $47 \%$ of respondents want to reduce the number of capital crimes down from $66 \%$ in 2006 [79]. The change also represents fluctuation in public opinion about the death penalty in Vietnam, the fluctuation which is hard to comprehend and anticipate and is very much dependent on the actual situation [95] (Table 8). 
Table 8. Deterrent effect of capital punishment.

\begin{tabular}{cccc}
\hline No. & Deterrent Effect of Capital Punishment & Number of Questionnaires & Proportion \\
\hline 1 & No effect & 01 & $2 \%$ \\
\hline 2 & Low & 06 & $12 \%$ \\
\hline 3 & Average & 20 & $40 \%$ \\
\hline 4 & High & 22 & $44 \%$ \\
\hline 5 & Other opinion & 01 & $2 \%$ \\
\hline
\end{tabular}

\section{Concluding Remarks}

Throughout the paper, it has been demonstrated that capital punishment is a very controversial issue in Vietnam. Once a prominent feature of the criminal law with over-use and application, capital crimes have now been reduced significantly. The downsize of capital crimes is not only in tune with the international trend, it also illustrates the growing awareness of and respect for human rights and the rule of law in Vietnam. However, much still needs to be done to further reduce the number of capital crimes or abolish it altogether. In the course of reducing capital crimes, political, cultural, and economic, as well as ideological considerations, must be taken into consideration to better comprehend the legacy of capital punishment in Vietnam and how to tackle it. The issue of capital punishment is attracting increasing attention by the public in Vietnam, especially when the National Assembly recently adopted the new 2015 Criminal Code which includes, but reduces the number of capital offences. The deterrent effect of the capital punishment is now at the center of the debate in Vietnam with recent discussions in many forums including the National Assembly pointing to the fact that public opinion polls continue to demonstrate that a majority support the death penalty as an effective deterrent.

As referred to above, with respect to the government's position, it is possible that Vietnam has been in tune with global trends demonstrated by the reduction in capital crimes from 44 in the 1985 Penalty Code to 29 provisions in the 1999 Penalty Code, and subsequently, to 25 provisions in the amended 1999 Penalty Code which was adopted in the latest session of 12th National Assembly in 2009 and to 18 crimes in the 2015 Criminal Code. The motivation for these changes has several possible explanations: Firstly, since Vietnam is integrating deeply into every aspect of international life and the legal system in general and penal judiciary are required to comply with international standards. Secondly, the issue of the death penalty is invariably raised in the multilateral and bilateral dialogues about human rights held between Vietnam and many other countries and organizations. And thirdly, it is in response to the efforts of the United Nations, European Union and the Council of Europe and their strategies to limit the use of capital punishment leading to a moratorium and final de jure abolition [73].

However, there are remaining factors constraining the removal of capital punishment in Vietnam in the near future, the most pressing being the rise in crime, especially dangerous crimes such as murder and narcotics crimes [89]. This not only puts pressure on the government authorities to find effective prevention methods but also affects public sentiments to the application of strict punishments to criminals. Predictably, the majority of the public, the competent bodies, and even the National Assembly delegates favor the retention of capital punishment for such very dangerous crimes. From a government perspective in 2007 and 2008, when the United Nations General Assembly voted to pass the resolution aiming at a moratorium on executions Vietnam abstained on both occasions indicating that Vietnam did not oppose the resolutions but was not yet ready to vote in favor of the resolution to adopt a moratorium [74]. 
Author Contributions: Conceptualization: K.T. and C.G.V.; Writing-Original Draft Preparation: K.T. and C.G.V.; Writing-Review and Editing: K.T.

Funding: This research was funded by Vietnam National Foundation for Science and Technology Development (NAFOSTED) under grant number 505.01-2017.02 and 505.02-2017.02.

Acknowledgments: The authors of the research would like to extend their thanks to Sébastien Lafrance, Counsel of the Public Prosecution Service of Canada for his useful comments on the early draft of this article. The authors also want to thank Pham Ho Nam and Tran Hoang Anh for their research assistance.

Conflicts of Interest: The authors declare no conflict of interest.

\section{References}

1. Encyclopedia Britannica. Available online: http://www.britannica.com/topic/capital-punishment (accessed on 29 May 2016).

2. Amnesty International, Amnesty International Global Report. Death Sentences and Executions Reports 2015; Amnesty International: London, UK, 2015.

3. Commission on Human Rights. Summary or Arbitrary Executions: Report by the Special Rapporteur; The Economic and Social Council and the Commission on Human Rights, 1988. Available online: https://documents-ddsny.un.org/doc/UNDOC/GEN/G88/101/60/PDF/G8810160.pdf?OpenElement (accessed on 9 April 2019).

4. Amnesty International, Amnesty International Global Report. Death Sentences and Executions 2017; Amnesty International: London, UK, 2017; p. 48.

5. Amnesty International, Amnesty International Global Report. Death Sentences and Executions Reports 2016; Amnesty International: London, UK, 2016.

6. Amnesty International. Abolitionist and Retentionist Countries (As of July 2018); Amnesty International: London, UK, 2018.

7. Amnesty International. The Amnesty International Report 2017/18; Amnesty International: London, UK, 2018.

8. 117 Countries Vote for a Global Moratorium on Executions. Available online: http://www.worldcoalition. org/united-nations-resolution-moratorium-death-penalty-executions-general-assembly.html (accessed on 9 April 2019).

9. Johnson, D.T.; Zimring, F.E. The Next Frontier National Development, Political Change, and the Death Penalty in Asia; Oxford University Press: Oxford, UK, 2009.

10. Hodgkinson, P.; Rutherford, A. (Eds.) Capital Punishment Global Issues and Prospects; Waterside Press: Loddon, UK, 1996.

11. The United Nations Office of the High Commissioner for Human Rights. Moving Away from Death Penalty in South-East Asia-Baseline Study; The United Nations Office of the High Commissioner for Human Rights: Bangkok, Thailand, 2015.

12. Walen, A. Retributive Justice. In the Stanford Encyclopedia of Philosophy; Zalta, E.N., Ed.; Metaphysics Research Lab, Stanford University: Stanford, CA, USA, 2016.

13. Radelet, M.L.; Borg, M.J. The changing nature of death penalty debates. Annu. Rev. Sociol. 2000, $26,43-61$. [CrossRef]

14. Nghia, P.D. Confucianism and the conception of the law in Vietnam. In Asian Socialism and Legal Change: The Dynamics of Vietnamese and Chinese Reform; The Australian National University: Canberra, Australia, 2005; pp. 76-90.

15. Son, B.N. Confucian Constitutionalism in Imperial Vietnam. NTU L. Rev. 2013, 8, 373.

16. Nghia, T.T. The Rule of Law in Vietnam: Theory and Practice. In the Rule of Law Perspectives from the Pacific Rim; The Mansfield Centre for Pacific Affairs, Ed.; The Mansfield Centre for Pacific Affairs: New York, NY, USA, 2000.

17. Trịnh, Q.T. Chế định hình phạt tử hình trong Luật hình sự Việt Nam và một số kiến nghị hoàn thiện. Tạp chí Khoa học ĐHQGHN Luật học 2012, 28, 30-41.

18. Lê, V.C.; Nguyễn, T.L. Hình phạt tử hình trong pháp luật hình sự Việt Nam: Giữ nguyên hay cần giảm và tiến tới loại bỏ (?). Tạp chí Khoa học ĐHQGHN, Luật học 2014, 30, 1-14.

19. Nicholson, P.; Truong, K. Drugs Prosecutions in Vietnam: The Modern Propaganda Trial. Monash UL Rev. 2008, 34, 430 . 
20. Nguyen, T.P.H. Drug-Related Crimes under Vietnamese Criminal Law: Sentencing and Clemency in Law and Practice; University of Melbourne, Centre for Indonesian Law, I. and S. \& University of Melbourne, Asian Law Centre: Melbourne, Australia, 2014.

21. Lương, T.H. The Application of the Death Penalty for Drug-Related Crimes in Vietnam: Law, Policy, and Practice. Available online: http://thailawforum.com/articles/Vietnam-death-penalty.html (accessed on 28 June 2019).

22. Lindsey, T.; Nicholson, P. Drugs Law and Legal Practice in Southeast Asia: Indonesia, Singapore and Vietnam; Bloomsbury Publishing: London, UK, 2016; ISBN 1-78225-833-7.

23. Vu, C.G. Capital Punishment in Vietnam: Status and Perspective. In Capital Punishment: New Perspective; Hodgkinson, P., Ed.; Routledge: Abingdon, UK, 2016.

24. Vu, T.P. Giao Trinh Lich Su Nha Nuoc va Phap Luat Viet Nam (Textbook on the History of State and Law of Vietnam); Vietnam National University Press: Hanoi, Vietnam, 2007.

25. Vu, Q.T. Phap che su Viet Nam (The History of Law of Vietnam); Saigon University Textbook: Saigon, Vietnam, 1971.

26. Nguyen, N.H.; Ta, V.T.; Tran, V.L. The Le Code: Law in Traditional Vietnam; Ohio University Press: Athens, $\mathrm{OH}$, USA, 1987; Volume 1.

27. Yang, X. The Confucianization of Law and Lenient Punishments in China. Int. J. Crim. Justice Sci. 2015, $10,32-47$.

28. Bui Xuan Dinh Hinh phat va viec ap dung hinh phat thoi Nguyen giai doan 1802-1858 (Situation on crimes and the application of penalties under Nguyen Dynasty in the period of 1802-1858). State Law J. 2000, 8.

29. Lu, H.; Terance, D. Miethe China's Death Penalty: History, Law and Contemporary Practices; Routledge: Abingdon, UK, 2007.

30. Marzilli, A. Capital Punishment: Point Counterpoint, 2nd ed.; Infobase Publishing: New York, NY, USA, 2008.

31. Cheng, C.H. The Chinese Theory of Criminal Law. J. Crim. Law Criminol. 1949, 39, 461-470. [CrossRef]

32. Juergensmeyer, M. Religion in Global Civil Society; Oxford University Press: Oxford, UK, 2005.

33. Collins, S. Nirvana and other Buddhist Felicities: Utopias of the Pali Imaginaire; Cambridge University Press: Cambridge, MA, USA, 1998.

34. Rodney, L. Taylor Cheers or Tears: What Confucius Would Say about Texas Executions. Available online: http://www.huffingtonpost.com/rodney-1-taylor-phd/cheers-or-tears-texas-or-_b_1002603.html (accessed on 29 May 2016).

35. Bodde, D.; Morris, C. Law in Imperial China; Harvard University Press: Cambridge, MA, USA, 1967.

36. Van Huu, L.; Tien, P.P.; Lien, N.S. (Eds.) Đại Việt Sử Ký Toàn Thu (Complete Annals of Dai Viet); Social Sciences Publishing House: Hanoi, Vietnam, 1993.

37. De Raulin, A.; Pastorel, J.; Toan, T.Q.; Anh, N.H. (Eds.) Ngo Huy Cuong Su Anh Huong Cua Phap Luat Phap Toi Luat Tu o Viet Nam. In Anh Huong Cua Truyen Thong Phap Luat Phap toi Phap Luat Viet Nam; Vietnam National University Press: Hanoi, Vietnam, 2016.

38. Quigley, J. Vietnam's First Modern Penal Code. J. Int. Comp. Law 1988, 9, 143-193.

39. Bedau, H.A.; Kelly, E.; Edward, N. Zalta Punishment. Available online: https://plato.stanford.edu/archives/ fall2015/entries/punishment/ (accessed on 29 May 2016).

40. Walen, A.; Edward, N. Zalta Retributive Justice. Available online: https://plato.stanford.edu/archives/ win2016/entries/justice-retributive/ (accessed on 29 May 2018).

41. Van Loi, P. Ve Hinh Phat tu Hinh va viec Thi Hanh Hinh Phat tu Hinh (on the Death Penalty and the Implementation of Death Penalty); National Politics Publishing House: Hanoi, Vietnam, 2006.

42. Đắc Lập. Hoang Viet Hinh Luat; Đắc Lập: Huế, Vietnam, 1933.

43. Nickel, J. Human Rights. The Stanford Encyclopedia of Philosophy. Available online: https://plato.stanford.edu/ entries/rights-human/ (accessed on 9 April 2019).

44. Declaration of Independence of Vietnam. 1945. Available online: https://tuoitre.vn/tuyen-ngon-doc-lapnuoc-viet-nam-dan-chu-cong-hoa-217980.htm (accessed on 9 April 2019).

45. Constitution of Vietnam. 1946. Available online: https://huvienphapluat.vn/van-ban/Bo-may-hanh-chinh/ Hien-phap-1946-Viet-Nam-Dan-Chu-Cong-Hoa-36134.aspx (accessed on 9 April 2019).

46. Uc, D.T. The Socialist Rule of Law State of Vietnam-Major Achievements over a Sixty Year Process of its Building and Development. Soc. Sci. Inf. Rev. 2007, 1, 3-12. 
47. President of the Interim Government of Democratic Republic of Vietnam. Decree No.47/SL on the Temporary Use of the Old Code, except for Changes Identified in This Decree. 1945. Available online: https://thuvienphapluat.vn/van-ban/Bo-may-hanh-chinh/Sac-lenh-so-47-giu-tam-thoi-luat-le-hienhanh-Bac-Trung-Nam-bo-ban-hanh-nhung-bo-luat-phap-duy-nhat-toan-quoc-35893.aspx (accessed on 9 April 2019).

48. President of the Interim Government of Democratic Republic of Vietnam. Decree No.60/SL on the Procedural Laws Applied before the Court of Hanoi, Hai Phong, South of Vietnam, and Da Nang. 1945. Available online: https://huvienphapluat.vn/van-ban/Bo-may-hanh-chinh/Sac-lenh-60-tam-thoi-luat-le-hien-hanhBac-Trung-Nam-bo-Sac-lenh-10-10-45-35909.aspx (accessed on 9 April 2019).

49. President of the Democratic Republic of Vietnam. Decree No.97/SL on the Amendments of Provisions and Regulations in Civil Law. 1950. Available online: https://thuvienphapluat.vn/van-ban/Quyen-dan-su/Saclenh-97-SL-sua-doi-quy-le-che-dinh-dan-luat/36573/noi-dung.aspx (accessed on 9 April 2019).

50. President of the Democratic Republic of Vietnam. Decree No.150/SL on the Establishment of the Special People's Courts in Area Land Policy is Implemented; 1953; Available online: https: //thuvienphapluat.vn/van-ban/Bat-dong-san/Sac-lenh-150-SL-thanh-lap-Toa-an-nhan-dan-Dac-bietnoi-phat-dong-quan-chung-thi-hanh-chinh-sach-ruong-dat-36726.aspx (accessed on 9 April 2019).

51. Quigley, J. Vietnam at a Legal Crossroads Adopts a Penal Code. Am. J. Comp. Law 1988, 36, 351-357. [CrossRef]

52. Phuong-Khanh, T. Nguyen The Criminal Code of the Socialist Republic of Vietnam. Rev. Soc. Law 1987, 13, 103-105.

53. Ministry of Justice. Circular No.19/NHH-HS on the Application of Law. quoted in Directive No.772 of Supreme People's Court. 1955. Available online: https://huvienphapluat.vn/van-ban/Bo-may-hanh-chinh/Chi-thi-772TATC-dinh-chi-ap-dung-luat-phap-cu-de-quoc-phong-kien/22871/noi-dung.aspx (accessed on 9 April 2019).

54. Supreme Court of Vietnam. Directive No. 772-TATC on Suspension of the Colonial and Feudal Laws; 1959; Available online: https:/thuvienphapluat.vn/van-ban/Bo-may-hanh-chinh/Chi-thi-772-TATC-dinh-chi-apdung-luat-phap-cu-de-quoc-phong-kien/22871/noi-dung.aspx (accessed on 9 April 2019).

55. Law on the Organization of People's Court. 1960. Available online: https://thuvienphapluat.vn/van-ban/Bomay-hanh-chinh/Luat-to-chuc-Toa-an-nhan-dan-1960-19-LCT-36862.aspx (accessed on 9 April 2019).

56. Gillespie, J. Changing Concepts of Socialist Law in Vietnam. In Asian Socialism Legal Change: The Dynamics of Vietnamese and Chinese Reforms; Gillespie, J., Nicholson, P., Eds.; Australian National University E Press: Canberra, Australia, 2005.

57. Los, M. Communist Ideology, Law and Crime: A Comparative View of the USSR and Poland; Macmillan Press: London, UK, 1988.

58. The Penal Code of Vietnam. 1985. Available online: https://thuvienphapluat.vn/van-ban/Trach-nhiem-hinhsu/Bo-luat-Hinh-su-1985-17-LCT-HDNN7-37003.aspx (accessed on 9 April 2019).

59. Sunstein, C.R.; Vermeule, A. Is Capital Punishment Morally Required? Acts, Omissions, and Life-Life Trade offs. Standford Law Rev. 2006, 58, 703.

60. World Bank Group; Ministry of Planning and Investment of Vietnam. Vietnam 2035: Toward Prosperity, Creativity, Equity, and Democracy; World Bank: Washington, DC, USA, 2016.

61. Schabas, W. The Abolition of the Death Penalty in International Law; Cambridge University Press: Cambridge, MA, USA, 2002.

62. Vietnam Bar Association. Death Penalty in International Law; Hong Duc Publishing House: Hanoi, Vietnam, 2008.

63. Constitution of Vietnam. 2013. Available online: https://thuvienphapluat.vn/van-ban/Bo-may-hanh-chinh/ Hien-phap-nam-2013-215627.aspx (accessed on 9 April 2019).

64. Tuan, N.M. Legitimate Limitations on Human Rights and Citizen Rights in International Law and Vietnamese Law; Hong Duc Publishing House: Hanoi, Vietnam, 2015.

65. Phuong Thao Thu Hep Pham Vi Ap Dung An Tu Hinh Trong Bo Luat Hinh Su 1999 (Narrowing the Scope of Criminal Offences in the 1999 Criminal Code). Available online: http://www.noichinh.vn/nghien-cuu-trao-doi/ 201312/thu-hep-pham-vi-ap-dung-hinh-phat-tu-hinh-trong-bo-luat-hinh-su-nam-1999-293434/ (accessed on 29 May 2018). 
66. Nguyen Ngoc Anh Van De Giam Hinh Phat Tu Hinh Trong BLHS (Sua Doi) (On the Reduction of Capital Crimes in the Amended Criminal Code). Available online: http://cand.com.vn/Van-de-hom-nay-thoi-su/ Van-de-giam-hinh-phat-tu-hinh-trong-BLHS-sua-doi-370480/ (accessed on 29 May 2018).

67. Bộ Ngoại Giao. Bảo vệ và Thúc Đẩy Quyền con Người ở Việt Nam; Hà Nội: Hanoi, Vietnam, 2018.

68. Human Rights Council. Report of the Working Group on the Universal Periodic Review: Vietnam; United Nations: New York, NY, USA, 2019.

69. Human Rights Council. Report of the Working Group on the Universal Periodic Review: Vietnam Addendum; United Nations: New York, NY, USA, 2019.

70. Lan, N.T. Nguyen Thi Lan Hinh Phat Tu Hinh Trong Phap Luat Hinh Su Viet Nam: Giu Nguyen Hay Can Giam Va Tien Toi Loai Bo? (Death Penalty in Vietnamese Criminal Law: Retention or Reduce and Abolition?). VNU J. Sci. Leg. Stud. 2014, 30, 1-14.

71. Nguyen Ngoc Chi Mot So Suy Nghi Ve Hinh Phat Tu Hinh Trong Luat Hinh Su Viet Nam (Some Thoughts on Capital Punishment in Vietnam). VNU J. Sci. Leg. Stud. 2012, 28, 42-48.

72. Van Beo, P. On Death Penalty in Vietnamese Criminal Law; National Politics Publishing House: Hanoi, Vietnam, 2010.

73. Uc, D.T.; Giao, V.C.; Ha, T.T.H. (Eds.) The Right to Life and Death Penalty; National Politics Publishing House: Hanoi, Vietnam, 2015.

74. National Assembly. Available online: http://www.na.gov.vn/htx/Vietnamese (accessed on 29 May 2018).

75. National Assembly. Resolution No.33/2009/QH12 on Implementing the Law Amending, Supplementing the 1999 Criminal Code; 2009; Available online: https:/thuvienphapluat.vn/van-ban/Trach-nhiem-hinh-su/Nghi-quyet33-2009-QH12-thi-hanh-Luat-bo-sung-Bo-luat-Hinh-su-91169.aspx (accessed on 9 April 2019).

76. Vu Thi Thuy Limiting the Death Penalty in Vietnamese Criminal Law: Changes from the Criminal Code 1999 to Criminal Code 2015; Ho Chi Minh City Law University: Ho Chi Minh, Vietnam, 2017.

77. Criminal Code of Vietnam. 2015. Available online: https://thuvienphapluat.vn/van-ban/Trach-nhiem-hinhsu/Bo-luat-hinh-su-2015-296661.aspx (accessed on 9 April 2019).

78. Criminal Procedure Code of Vietnam. 2015. Available online: https://thuvienphapluat.vn/van-ban/Trachnhiem-hinh-su/Bo-luat-to-tung-hinh-su-2015-296884.aspx (accessed on 9 April 2019).

79. Law on Criminal Execution of Vietnam; 2010; Available online: https:/thuvienphapluat.vn/van-ban/Trachnhiem-hinh-su/Luat-thi-hanh-an-hinh-su-2010-108086.aspx (accessed on 9 April 2019).

80. Nguyen Xuan Yem Lethal Injection A New Method of Execution in Vietnam. Available online: http://www.hvcsnd.edu.vn/vn/Acedemy/Phap-luat/84/955/Tiem-thuoc-doc-Mot-bien-phap-thihanh-an-tu-hinh-moi-o-Viet-Nam.aspx (accessed on 17 June 2017).

81. Law on Mutual Legal Assistance. 2007. Available online: https://thuvienphapluat.vn/van-ban/Thu-tuc-Totung/Luat-tuong-tro-tu-phap-2007-08-2007-QH12-59655.aspx (accessed on 9 April 2019).

82. Phuong Ha Death Penalty Injection Will Start from December 2011. Available online: http://anninhthudo. vn/An-ninh-doi-song/Tu-hinh-bang-tiem-thuoc-doc-se-bat-dau-tu-thang-122011/425765.antd (accessed on 29 May 2018).

83. Prime Minister. Decision No.01/2004/QD-TTg on the List of State Secret Information of the People's Courts. 2004. Available online: https://huvienphapluat.vn/van-ban/Bo-may-hanh-chinh/Quyet-dinh-01-2004-QD-TTgDanh-muc-bi-mat-nha-nuoc-do-toi-mat-nganh-Toa-an-nhan-dan-52406.aspx (accessed on 9 April 2019).

84. Human Rights Committee. General Comment No. 36 (2018) on Article 6 of the International Covenant on Civil and Political Rights, on the Right to Life; Human Rights Committee. Available online: https://tbinternet.ohchr. org/Treaties/CCPR/Shared\%20Documents/1_Global/CCPR_C_GC_36_8785_E.pdf (accessed on 9 April 2019).

85. The Kha Building Five More Capital Execution Centers Using Lethal Injection Method. Available online: http://dantri.com.vn/xa-hoi/xay-dung-them-5-nha-thi-hanh-an-tu-hinh-bang-tiem-thuoc-doc20170208114147149.htm (accessed on 29 May 2018).

86. Hutt, D. Beware Vietnam's Death Machine. Available online: http://thediplomat.com/2017/04/bewarevietnams-death-machine/ (accessed on 29 May 2018).

87. Nhung, T. 8 Death Sentences for a Criminal Gang Trading 1200 Boxes of Drugs. Available online: http://vietnamnet.vn/vn/phap-luat/ky-su-phap-dinh/8-an-tu-hinh-cho-duong-day-ma-tuy-gan1-200-banh-370081.html (accessed on 29 May 2018).

88. The Death Penalty in Vietnam. Available online: https://www.deathpenaltyworldwide.org/country-searchpost.cfm?country=Vietnam (accessed on 30 June 2019). 
89. Phạm, V.T. Tổng quan về mức độ của tình hình phạm tội ở Việt Nam qua số liệu thống kê từ năm 1986-2008 (General Statistics of Criminal Situations in Vietnam from 1986-2008). Tạp chí Nhà nước và Pháp luật 2011, 4. Available online: http://tks.edu.vn/thong-tin-khoa-hoc/chi-tiet/80/5 (accessed on 9 April 2019).

90. Vidmar, N.; Ellsworth, P. Public opinion and the death penalty. Stan. L. Rev. 1973, 26, 1245. [CrossRef]

91. Norrander, B. The Multi-Layered Impact of Public Opinion on Capital Punishment Implementation in the American States. Political Res. Q. 2000, 53, 771-793. [CrossRef]

92. Public Opinion on the Death Penalty. Available online: https://www.deathpenaltyworldwide.org/publicopinion.cfm (accessed on 10 July 2019).

93. Shirley, K.E.; Gelman, A. Hierarchical models for estimating state and demographic trends in US death penalty public opinion. J. R. Stat. Soc. 2014, 178, 1-28. [CrossRef]

94. School of Law. Survey Project on Death Penalty: Report of Findings; School of Law-Vietnam National University Hanoi: Hanoi, Vietnam, 2011.

95. Haines, H.H. Against Capital Punishment: The Anti-Death Penalty Movement in America 1972-1994; Oxford University Press: Oxford, UK, 1999.

(C) 2019 by the authors. Licensee MDPI, Basel, Switzerland. This article is an open access article distributed under the terms and conditions of the Creative Commons Attribution (CC BY) license (http://creativecommons.org/licenses/by/4.0/). 